\title{
Mannose-Binding Protein C
}

National Cancer Institute

\section{Source}

National Cancer Institute. Mannose-Binding Protein C. NCI Thesaurus. Code C68581.

Mannose-binding protein C (248 aa, $26 \mathrm{kDa}$ ) is encoded by the human MBL2 gene. This protein plays a role in the initiation of targeted host defense mechanisms against pathogens by activating the complement pathway. 